\title{
PENYIMPANGANAN PERILAKU REMAJA DI PERKOTAAN
}

\author{
Ni Made Suwendri \\ Universitas Warmadewa \\ suwendri63@gmail.com \\ Ni Ketut Sukiani \\ Universitas Warmadewa \\ ketutsukiani@gmail.com
}

\begin{abstract}
ABSTRAK
Remaja sebagai generasi penerus memiliki peran penting dalam pembangunan bangsa. Di sisi lain remaja sering dihadapkan kepada masalah sosial. Sosialisasi yang dilakukan terkadang tidak sesuai dengan nilai, norma yang berlaku di masyarakat. Permasalahan yang diangkat dalam penelitian ini adalah faktor penyebab terjadinya penyimpangan perilaku remaja di perkotaan, bagaimana bentukbentuk penyimpangan perilaku remaja di perkotaan, dan bagaimana upaya mengatasi penyimpangan perilaku remaja di perkotaan. Penelitian ini bertujuan mengetahui faktor penyebab terjadinya penyimpangan perilaku remaja di perkotaan, mengetahui bentuk-bentuk penyimpangan perilaku remaja di perkotaan, dan mengetahui upaya mengatasi penyimpangan perilaku remaja di perkotaan. Landasan teori yang digunakan dalam mengkaji masalah ini adalah teori kontrol sosial dan teori labeling. Penelitian ini menggunakan metode kualitatif. Sumber data diperoleh dari penelitian perpustakaan (library research). Analisis data dilakukan secara kualitatif dengan teknik penyajian yang bersifat deskriptif kualitatif. Penelitian ini membuktikan bahwa penyimpangan perilaku remaja di perkotaan terjadi semakin marak. Bentuk-bentuk penyimpangan perilaku remaja di perkotaan seperti, penyalahgunaan narkotika, tawuran antar geng, mabuk-mabukan, dan merokok. Motif penyebab penyimpangan perilaku adalah pengaruh kegagalan sosialisasi, kontrol sosial yang lemah (kekosongan kontrol), dan pemberian label/cap atau julukan oleh masyarakat kepada seseorang yang kemudian cenderung mengidentifikasikan dirinya sebagai penyimpang.
\end{abstract}

Kata kunci:faktor-faktor; penyimpangan perilaku; remaja

\begin{abstract}
Adolescents as the next generation have an important role in the development of the nation. On the other hand, they frequently face social problems. The socialization they make sometimes deviates from the values, the norms prevailing in the society. The problems of this study are what factors causing the behavioral deviation of the urban adolescent, what several of the behavioral deviation of the urban adolescent, and what efforts should be taken to overcome the behavioral deviation of the urban adolescent. This study aims to determine the factors causing the behavioral deviation of the urban adolescent, to know the several of the behavioral deviations of the urban adolescent, and to find out the efforts to overcome the behavioral deviation of the urban adolescent. The theoretical basis used in examining the problems is the theory of social control and labeling theory. This study used a qualitative method. The data source was obtained from library research. The data were analyzed with the qualitative descriptive presentation technique. The result of this study showed that the deviation of adolescent behavior in urban areas is increasing highly. Several of the behavioral deviation of the urban adolescent such as juvenile delinquency, drug abuse, brawl, drunkenness, and smoking. The motives are such as the failure of socialization, weak of social control (no controller), and labeling to someone who tends to identify himself as the one who does deviation by society.
\end{abstract}

Keywords:factors; negative behavior; youth 


\section{PENDAHULUAN}

Beberapa literatur menyatakan bahwa remaja atau generasi muda adalah mereka yang berusia 11-23 tahun dan masih dalam tahap pencarian identitas diri (Soelaeman, 2009: 105 -106). Remaja berperan penting dalam kemajuan bangsa.

Dalam GBHN dijelaskan secara ringkas bahwa peran generasi muda dalam masyarakat dan bangsa adalah sebagai calon penerus perjuangan bangsa. Oleh karena itu, mereka harus dibekali keterampilan, kepemimpinan, kesehatan jasmani, kemampuan berkreasi, patriotisme, pandangan hidup, kepribadian, dan budi pekerti yang luhur. Berdasarkan hal tersebut, perlu duwujudkan kebijaksanaan nasional tentang kepemudaan secara menyeluruh dan terpadu. Terdapat berbagai wadah pembinaan generasi muda diamtaranya adalah sekolah, organisasi fungsional pemuda (pramuka, organisasi olahraga, dan lain-lain). Demikian juga peran remaja atau generasi muda dalam pembangunan antara lain: (a) Generasi muda sebagai penerus tradisi. Mereka berusaha menyesuaikan diri dengan tuntutan lingkungannya, dalam hal ini mentaati tradisi yang berlaku. (b) Generasi muda sebagai pembangkit. Pemuda pembuka kejelasan dari suatu masalah sosial. Generasi muda pembangkit ini memperjuangkan masyarakat marginal (terpinggirkan) atau masyarakat yang tidak menikmati hasil pertumbuhan pembangunan.

Dengan demikian, dapat dikatakan remaja merupakan tulang punggung bangsa, karena remajalah yang akan melanjutkan pembangunan suatu bangsa di masa depan. Dengan kata lain, remaja dituntut untuk berperilaku positif, kreatif, dan inovatif agar mampu membuat pembangunan bangsanya menjadi lebih baik.

Akan tetapi pada kenyataannya, banyak remaja yang berperilaku sebaliknya. Di kotakota besar acapkali terjadi penyimpangan perilaku di kalangan remaja (Pelly \& Menanti, 1994: 144 - 147). Penyimpangan perilaku yang dimaksud di sini yaitu perilaku negatif, perilaku buruk atau ketidaksesuaian sikap, perbuatan atau tingkah laku dengan aturan yang berlaku, sehingga tingkah lakunya tidak berkenan di masyarakat.
Atas dasar pemikiran tersebut di atas, permasalahan yang diangakat pada tulisan ini adalah: (1) Mengapa terjadi penyimpangan perilaku pada remaja di perkotaan? (2) Bagaimana bentuk-bentuk perilaku yang menyimpang pada remaja di perkotaan? (3) Bagaimana upaya mengatasi perilaku yang menyimpang di kalangan remaja perkotaan?

Tujuan mengkaji masalah ini yaitu: (1) Menemukan faktor penyebab terjadinya penyimpangan perilaku pada remaja di perkotaan. (2) Untuk mengetahui bentukbentuk perilaku yang digolongkan dalam perilaku menyimpang pada remaja. (3) Untuk mengetahui upaya mengatasi perilaku yang menyimpang di kalangan remaja perkotaan.

Landasan teori dalam artikel ini adalah teori kontrol sosial dan teori labeling. Kontrol sosial merupakan strategi dalam mengatur perilaku manusia kepada ketaatan terhadap nilai, norma, aturan yang berlaku di masyarakat. Menurut teori ini penyimpangan adalah kekosongan kontrol (pengendalian sosial). Teori ini memandang bahwa setiap manusia pada dasarnya cendrung tidak mentaati hukum sehingga terjadi pelanggaran (Adang, 2013: 102). Teori labeling memandang bahwa seseorang cendrung melakukan dan mengulangi lagi tindakan penyimpangan (penyimpangan skunder) karena terlanjur diberikan label atau cap oleh masyarakat (Narwoko, 2013: 114).

Beberapa kajian pustaka yang relevan. Usia remaja tergolong rentan dalam bersosialisasi. Sosialisasi yang dilakukan terkadang tidak sesuai dengan aturan yang berlaku di kehidupan masyarakat. Kegagalan remaja dalam menumbuhkan nilai dan norma yang positif dalam dirinya disebut dengan penyimpangan sosial atau penyimpangan perilaku.

Umami dan Panuju menyebutkan, masa remaja adalah masa stress and strain (masa kegoncangan dan kebimbangan) (Umani \& Panuju, 1999: 20). Hal ini berakibat kepada para remaja untuk melakukan penolakanpenolakan terhadap kebiasaan baik dalam lingkungan keluarga. Perilaku demikian potensial menimbulkan penyimpangan norma sosial. 
Clinard dan Meier dalam buku Narwoko dan Suyanto membedakan empat sudut pandang pengertian tentang perilaku menyimpang (deviance behavior) di kalangan remaja. Pertama dari sudut pandang secara statistikal adalah perilaku yang jarang atau tidak sering dilakukan. Kedua, pandangan secara absolut atau mutlak, disebutkan bahwa masyarakat menetapkan aturan secara jelas dan warga masyarakatnya harus setuju apa yang disebut sebagai tindakan menyimpang atau tidak. Ketiga, pandangan reaktif. Berkaitan dengan reaksi atau respon masyaraat sebagai kontrol sosial terhadap penyimpangan perilaku individu. Keempat, pandangan secara normatif, bahwa penyimpangan itu adalah pelanggaran atau bertentangan terhadap norma sosial (Narwoko, 2013: 81-84).

Analog dengan definisi yang dikemukakan oleh Clinard dan Meier dalam Narwoko, disebutkan pula bahwa terdapat tiga bentuk perilaku menyimpang berdasarkan jumlah individu yang terlibat. Pertama penyimpangan dilakukan sendiri. Kedua, penyimpangan yang dilakukan bersama-sama atau berkelompok. Ketiga, tindakan menyimpang yang dilakukan oleh suatu golongan dengan organisasi teratur, sehingga anggotanya taat dan tunduk terhadap norma golongan yang bersangkutan.

\section{METODE}

Metode kualitatif diaplikasikan pada penelitian ini dengan kata lain metode yang diterapkan adalah metode oservasi dan despkriptif analitis yang mengutamakan temuan atau fakta-fakta aktual berdasarkan hasil obervasi selama proses penelitian. Analitis yang dimaksud adalah mencermati dan selanjutnya menganalisisnya dengan hati-hati sesuai keperluan penelitian ini. Sumber data diperoleh dari penelitian perpustakaan (library research). Setelah data terkumpul kemudian dianalisis. Analisis data dilakukan secara kualitatif dengan teknik penyajian yang diaplikasikan adalah deskriptif kualitatif (Moleong, Lexy, 2010); (Suriasumantri, 2002: 173-175).

\section{PEMBAHASAN}

\section{Faktor Penyebab Penyimpangan}

Adapun faktor-faktor penyebab sebagai berikut:
1. Pergeseran peran keluarga

Keluarga adalah tempat utama dan pertama untuk mendidik pembentukan kepribadian anak. Oleh karena itu, keluarga sebagai unit sosial terkecil yang dimiliki manusia sebagai makhluk sosial sangat besar perannya dalam pertumbuhan dan perkembangan anak-anaknya. Keharmonisan lingkungan keluarga harus tetap dijaga. Hubungan yang baik meliputi orang tua dengan anak dan hubungan di antara anak-anak itu sendiri. Anak-anak yang dibesarkan dari disorganisasi keluarga yang disebabkan karena perceraian maupun kematian salah satu atau kedua orang tuanya akan cendrung memicu perilaku negatif pada anak (Soekanto, 2012). Dalam kondisi seperti ini, anak akan mengalami kekosongan bimbingan karena kurang atau tidak adanya bimbingan langsung dari orang tuanya.

Pada keluarga yang kurang mampu secara finansial, orang tua harus mencari nafkah untuk dapat menghidupi keluarga, oleh karena itu, tidak memiliki waktu untuk merawat anak-anaknya. Terdapat orang tua yang tidak mampu menyekolahkan anakanaknya, ditambah lagi perumahan yang kurang memenuhi syarat atau kurang layak huni. Sebaliknya pada keluarga yang mampu secara ekonomis, orang tua tampak sibuk dalam rangka mengembangkan prestise. Kepedulian orang tua terhadap perkembangan kepribadian anaknya kurang mendapat perhatian. Hal ini merupakan awal dari rentan nya kepribadian anak terhadap pengaruhpengaruh negatif dari luar.

Peran orang tua tidak hanya melakukan pemenuhan kebutuhan material pada anaknya dengan menghabiskan waktunya bekerja keras di luar rumah, tetapi juga harus memperhatikan kebutuhan nonmaterial. Anak-anak perlu mendapatkan perhatian yang langsung dari orang tuanya, cinta, keterbukaan, dan juga orang tua dapat berperan sebagai teman ketika anak-anak mencurahkan perasaannya. Kebutuhan nonmaterial inilah yang sering kali terabaikan di kalangan orang tua. Orang tua cenderung lebih mementingkan kebutuhan lahiriah anaknya 
dengan alasan kesibukan mencari uang tanpa memperhatikan perkembangan mentalitas anak-anaknya. Hal ini jauh lebih penting. Apabila kebutuhan nonmaterial tersebut tidak diperhatikan, maka anakanak akan mencari pelampiasan dan pelarian ke luar rumah. Perilaku yang demikian ini kadang kala mengarah ke halhal yang kurang bermanfaat bagi dirinya dan orang lain. Hal inilah yang menjadi benih-benih munculnya perilaku negatif pada remaja yang pada mulanya terjadi dalam lingkungan keluarga dan akhirnya tumbuh dan berkembang hingga meresahkan masyarakat. Anak-anak dari kalangan menengah ke atas akan menjadi sorotan di masyarakat, dan ditiru oleh anakanak yang berasal dari kalangan sosial yang lebih rendah. Perilaku tersebut memicu munculnya organisasi-organisasi pemuda/pemudi yang tidak resmi yang prilakunya tidak disukai.

2. Lingkungan sokolah yang kurang kondusif

Di samping lingkungan keluarga yang kurang mendidik, lingkungan sekolah pun menghadapi banyak persoalan dalam hubungan dengan pembinaan pengembangan kepribadian anak. Pada masa sekarang, perkembangan ilmu pengetahuan dan teknologi sangat meningkat cepat, hal ini ikut serta memberikan pengaruh dalam dunia pendidikan di Indonesia. Muatan kurikulum sering mengalami perubahan. Berbagai mata pelajaran yang diharapkan dapat memacu daya fikir anak telah mewarnai kurikulum dan silabus yang ditawarkan. Sebagaimana dilontarkan oleh pengamat di bidang pendidikan, tampaknya muatan materi pelajaran yang diberikandi sekolah-sekolah terlalu padat. Kondisi semacam ini dapat membuat sebagian siswa teralienasi dari proses pembelajaran itu sendiri. Kurang memberikan ruang gerak yang leluasa bagi anak dalam mengaktualisasikan diri dan kepribadiannya. Apa yang diinginkan tidak ditemukan secara utuh dalam pertemuan di kelas. Akibatnya, merekapun gagal beradaptasi. Mereka inilah kemudian mencari konpensasi ke dalam kegiatan di luar sekolah. Sebagian dari mereka berkeliaran, membolos, pergi tanpa tujuan. Mereka potensial menjadi anak nakal.

3. Lemahnya kontrol sosial dari lembaga masyarakat

Penyimpangan perilaku remaja terhadap nilai dan norma yang dianut oleh masyarakat dapat pula terjadi karena masyarakat itu sendiri mudah mentoleransi, memberikan kelonggaran dalam pengawasan terhadap anak-anak muda yang terbukti melanggar hukum, misalnya mabuk-mabukan, kumpul kebo, perkelahian antar anak muda, yang kesemuanya itu sudah dianggap sebagai hal yang biasa saja.

Masyarakat yang menganut sub kebudayaan menyimpang memberikan kecendrungan kuat terhadap remaja untuk berperilaku negatif. Terkadang tanpa disadari oleh para warganya bahwa perbuatan yang dilkukan itu ternyata menyimpang dari norma yang berlaku secara umum. Contoh remaja yang hidup dalam lingkungan yang dominan menggeluti pekerjaan sebagai prostitusi, maka pekerjaan seperti ini sudah dianggap biasa atau wajar untuk dilakukan. Kondisi seprti ini dapat membentuk sikap dan pola kelakuan yang negatif.

4. Kegagalan sosialisai

Ketidakberhasilan seorang individu dalam melakukan sosialisasi di lingkungannya dapat disebabkan oleh ketidakmampuannya mengadataptasikan perilakunya dengan nilai-nilai dan aturan yang ada di masyarakat. Akibatnya seseorang melakukan perbuatan yang tidak terpuji. Kegagalan sosialisasi dapat pula terjadi karena ketidaksanggupan individu untuk patuh terhadap aturan yang dipegang oleh masyarakat. Hal ini disebabkan oleh gangguan moral dan kondisi ekonomi yang kurang menguntungkan bagi dirinya. Akhirnya mereka melakukan penyimpangan terhadap aturan demi untuk memenuhi kebutuhan hidup. Misalnya banyak di kalangan anak muda di kota besar di Indonesia sebagai gelandangan dan pengemis (gepeng). Perilaku yang 
demikian ini lama-kelamaan dapat berkembang ke arah tindakan kriminal yang melanggar hukum seperti perampokan, pencurian, pembunuhan, pemerkosaan, dan sebagainya.

Pengaruh lingkungan pergaulan yang negatif dapat pula menjerumuskan remaja pada penyimpangan perilaku yang negatif pula. Misalnya remaja-remaja sering bergaul dengan temannya yang suka berkata-kata kasar, berbohong, membolos di luar jam sekolah dan lain-lain, maka secara otomatis remaja itu akan mengikuti atau meniru perilaku yang berdampak negatif itu. Ini dapat terjadi apabila remaja tidak selektif dalam bergaul. Remaja yang tidak mampu belajar dan membedakan tingkah laku baik dan dapat diterima ataupun tidak, maka mereka akan terjerat ke dalam perilaku nakal. Begitu juga bagi mereka yang telah mengetahui perbedaan dua tingkah laku tersebut, tetapi tidak mampu mengontrol diri untuk berperilaku sesuai dengan pengetahuaannya. Hal inilah yang menimbulkan kegagalan dalam menyosialisasikan diri dan kepribadiannya sesuai dengan aturan di masyarakat.

5. Pengaruh negatif media massa

Dalam era globalisasi dewasa ini, pengaruh media massa baik media cetak maupun elektronika sangat potensial membawa pengaruh negatif di kalangan remaja. Gambar-gambar, kartun, tayangan televisi yang sering menyajikan film-film tentang tindak kekerasan, fornografi, kehidupan seks bebas, dan sebagainya secara langsung maupun tidak langsung akan mempengaruhi emosi kejiwaan seseorang untuk berperilaku kurang baik, terlebih lagi pada anak tersebut belum siap mental dan akhlaknya mereka cendrung meniru mentah-mentah seluruh tayangan. Apa yang disaksikan itu seakan-akan dianggap mengajarkan sehingga patut ditiru. Kondisi demikian mudah mendorong remaja melakukan hal-hal yang menyimpang dari tatanan nilai dan aturan yang berlaku.
6. Pemberian label atau julukan dari mayarakat

Seseorang yang ketahuan bersalah melanggar hukum misalnya mengkonsumsi narkoba, membunuh, kemudian dijebloskan ke penjara. Setelah kembalinya ke masyarakat mereka sulit diterima dalam lingkungan sosialnya karena sudah dicap kurang baik. Kegagalan individu dalam pemulihan nama baik ini memicu terjadinya penyimpangan perilaku. Mereka cendrung mengulangi kembali perbuatan negatif yang sebelumnya pernah dilakukan karena sudah terlanjur dijuluki atau diberi label yang negatif oleh masyarakatnya.

7. Kesenjangan sosial ekonomi

Adanya gap yang tajam di bidang ekonomi antara orang kaya dan miskin memicu kecemburuan sosial terlebih individunya bermental negatif. Akibatnya seseorang mengambil jalan pintas guna mencukupi kebutuhan hidupnya misalnya dengan cara mencuri, merampok, menodong, dan berbagai modus kejahatan lainnya terpaksa dilakukan. Perilaku demikian banyak terjadi terutama di perkotaan di Indonesia.

\section{Bentuk-Bentuk Penyimpangan Perilaku Remaja di Perkotaan}

Bentuk-bentuk perilaku negatif remaja yang umum di perkotaan:

1. Penyalahgunaan Narkoba

Salah satu persoalan yang amat berkaitan dengan meningkatnya kenakalan remaja adalah masalah penyalahgunaan narkotika (mariyuana, heroin, morfin, kokain, barbiturates, dsb.). Sosialisasi mengenai narkoba sudah sering diadakan sesuai dengan program anti narkoba untuk pelajar/sekolah serta dukungan terhadap peraturan perundangan No 35 Tahun 2009 tentang narkotika, tetapi penggunanya setiap tahun semakin meningkat. Penelitian BNN (Badan Narkotika Nasional) di tahun 2013 dalam Jurnal P4GN 2013 membuktikkan bahwa penyalahgunaan narkoba sesuai tingkat pendidikan didominasi oleh tingkat Sekolah Menengah Atas. Pernyataan ini didukung oleh penelitian yang dilakukan Vikiat Ika 
Maharti mengungkapakan bahwa mayoritas penyalahgunaan narkoba adalah pada usia remaja dengan umur berkisar antara 15-19 tahun. Hasil penelitian Vikiat memberikan gambaran bahwa yang menawarkan narkoba lebi banyak di kalangan teman, di tempat kerja, di luar rumah, dan teman di sekitar rumah. Tingginya perilaku dan sikap pendukung penyalahgunaan narkoba, memudahkan seseorang terpuruk dalam penyalahgunaan narkoba.

Hal senada juga diungkapkan oleh Jimmy Simangunsong dalam hasil penelitiannya menyimpulkan bahwa faktor yang dominan penggunaan narkoba di kalangan remaja dipicu oleh faktor pegaulan dengan teman sepergaulan yang bebas dan tanpa kontrol sehingga remaja ikut terjerumus dan menggunakan narkoba (Simangunsong, 2015: 63) Motivasi untuk mengkonsusmsi obat-obatan terlarang tersebut masing-masing individu berbedabeda antara lain sebagai penenang pikiran, menghilangkan rasa sakit, menghasilkan euforia, agar dapat diterima sebagai anggota suatu kelompok. Seorang pemakai obat-obat terlarang biasanya hadir bersama individu-individu lain yang membentuk komunitas tersendiri (Usman, 1998: 154).

\section{Tawuran Antar Pelajar atau geng}

Kamus Besar Bahasa Indonesia (KBBI) memuat kata tawuran berarti perkelahian massal adalah perkelahian yang dilakukan beramai-ramai. Dengan demikian tawuran pelajar adalah perkelahian secara massal atau beramairamai antara satu kelompok pelajar dengan kelompok pelajar lainnya.

Tawuran antar pelajar dapat berawal dari hal-hal sepele tetapi kemudian menjadi besar karena emosi para remaja yng masih labil. Berawal dari sebuah kompetisi nonton bersama yang berakhir dengan perkelahian, tersenggol di kendaraan umum, saling melecehkan, berebut, dan bahkan tidak jarang ketika saling menatap bisa terjadi saling ketersinggungan dan perkataan yang awalnya dianggap guyonan dapat memicu terjadinya tawuran, karena dianggap menantang satu sama lain. Selain alasan tersebut, terdapat pula tawuran antar pelajar yang sudah dianggap mentradisi. Umumnya hal ini terkait dengan permusuhan antar sekolah secara menurun dari generasi ke generasi, menjadi dendam yang berkelanjutan. Oleh karenanya sewaktu-waktu dapat menyebabkan terjadi perkelahian.

Kata tawuran, tentunya sudah tidak asing lagi. hampir Berita tawuran antar remaja sangat sering termuat di media masa. Munculnya geng menyebabkan makin maraknya tawuran. Hasil penelitian Puput Wilujeng tentang perilaku agresi siswa SMK PGRI Surabaya mengungkapkan bahwa mereka (remaja) melakukan agresi verbal dan nonverbal apabila gengnya diperlakukan tidak baik, Mereka menyelesaikan masalah dengan berkelahi. Perilaku anarkis dapat terjadi di tengah-tengah masyarakat. Mereka tidak berpikir bahwa perbuatan adalah perbuatan tidak terpuji dan bisa menggangu ketentraman masyarakat. Bahkan, mereka berpikir bahwa mereka hebat jika masyarakat itu gentar terhadap geng/kelompok mereka.

3. Pengguna minuman keras dan mabukmabukan

Penyimpangan perilaku negatif di kalangan remaja juga terlihat dalam hal mengkonsumsi minuman keras. Perilaku negatf ini tidak hanya terjadi di kalangan remaja di perkotaan tetapi juga dilakukan oleh remaja di pedesaan. Sama halnya mabuk-mabukan identik dengan minuman keras. Minuman keras adalah minuman yang mengandung etanol. Etanol merupakan bahan psikoaktif. Bila mengkonsumsinya dapat menimbulkan penurunan kesadaran. Mengkonsumsi minuman keras, tidak berkisar pada dilarang atau tidak untuk digunakan tetapi karena alkohol yang terkandung dalam mirashol tersebut. Persoalannya adalah dalam kondisi yang bagaimana seseorang boleh mengkonsumsinya Di Indonesia, perdagangan minuman keras dibatasi. Tidak sembarang orang boleh meminumnya. Minuman keras adalah dapat menjadi sumber masalah karena bisa sangat 
mengganggu jalannya sistem sosial dalam masyarakat. Minuman keras dapat sebagai penyebab terjadinya tindakan kriminal. Alkohol yang terkandung dalam miras merupakan suatu racun protoplasmic (racun yang merusak protein) yang mempunyai efek depresan pada sistem syaraf. Ini dapat berakibat menurunnya kemampuan dalam pengendalian diri, pengendalian fisik, psikologis, maupun sosial. Akibat dari tidak mampunya untuk mengendalikan diri karena dalam keadaan mabuk, maka seseorang tersebut akan dengan mudah melakukan perbuatan yang membahayakan masyarakat di lingkungan sekitarnya, seperti melakukan tindak kekerasan dan penganiyayaan

Penelitian tentang perilaku minumminuman keras di kalangan remaja di kabupaten Indragiri Hilir dilakukan oleh Agnes Siswendi. Disimpulkan bahwa munculnya perilaku buruk tersebut dipicu oleh pengaruh lingkungan keluarga yang tidak kondusif dan kuatnya pengaruh teman sebaya. Seorang remaja harus bisa menjalankan peran yang telah ditetapkan oleh kelompok sebayanya, sehingga mereka bias diterima di dalam kelompok tersebut. Untuk memenuhi keinginan terhadap minuman keras remaja tersebut terkadang melakukan tindakan criminal (Siswendi, 2014: 9-11). Penelitian yang dilakukan oleh Rori tentang pengaruh minuman keras pada kehidupan remaja $\mathrm{d}$ kabupaten Minahasa menyimpulkan hasil penelitiannya bahwa sebagian besar remaja menggunakan minuman keras (beralkohol) tersebut untuk menyelesaikan masalahnya. Remaja mabuk-mabukan karena beban pikiran dan prustasi. Mereka mencari pelampiasan dengan mabuk. Bagi mereka, mabuk dapat menghilangkan dan menyelesaikan masalah (Rori, 2015: 11).

\section{Merokok}

Laporan WHO (World Health Organization) tahun 2008 mengungkapkan bahwa rokok merupakan salah satu pembunuh paling ampuh. Rokok merupakan salah satu bahan yang dapat mengganggu kesehatan dan mengakibatkan seseorang kehilangan nyawa. Kebiasaan merokok adalah sebuah kenikmatan bagi para perokok. Efek mengkonsumsi rokok adalah dapat dilihat dan dirasakan dalam jangka pendek ataupun jangka panjang bagi penghisapnya. Rokok mengandung zat yang dapat mengganggu kesehatan manusia terutama kepada penghisapnya. Terdapat zat yang berbahaya yang terkandung dalam rokok yaitu Nikotin (terdapat pada daun tembakau), karbon monoksida (CO) terdapat pada asap rokok, Tar (komponen pada asap rokok) Tar sifatnya Karsinogen yaitu pemicu kanker.

Beberapa hasil penelitian yang terkait dengan salah satu bentuk penyimpangan perilaku remaja dalam hal mengkonsumsi rokok. Samrotul Fikriyah dalam penelitiannya tentang faktor-faktor yang mempengaruhi perilaku merokok pada mahasiswa laki-laki di Asrama Putra STIKES RS Baptis Kediri, menyimpulkan hasil penelitiannya bahwa faktor yang paling utama pemicu perilaku merokok di kalangan mahasiswa tersebut adalah karena faktor psikologis. Merokok dianggap memberikan kepuasan. Rokok diyakini dapat mendatangkan efek yang menyenangkan, nikmat, tenang, santai, hangat, percaya diri (Fikriyah \& Febrijanto, 2012: 108). Penelitian yang dilakukan Febriana Rahayuningsih tentang hubungan antara persepsi merokok dan perilaku merokok siswa SMK X di kota Semarang mengungkapkan bahwa sebagian besar remaja merokok dalam usia 17-20 tahun. Sebagian besar dari mereka berjenis kelamin laki-laki termasuk dalam katagori anak sekolah. Sebagian besar remaja merokok tersebut memiliki tingkat pengetahuan yang rendah tentang praktik merokok (Rahayuningsih, 2015: 225).

5. Seks bebas

Seks bebas merupakan prilaku yang dipicu oleh gairah seksual yang dilakukan oleh lawan jenis laki-laki dan perempuan tanpa memiliki ikatan pernikahan yang syah, saling suka maupun dalam dunia prostitusi. Masalah perilaku seksual pranikah di kalangan remaja di era globalisasi dewasa ini memang bukan rahasia lagi. Penelitian yang dilakukan 
Dani Andriansyah tentang perilaku seks bebas di kalangan remaja kota Tanjung Pinang (Studi tentang kontrol sosial remaja perilaku seks bebas), mengungkapkan bahwa perilaku seks bebas di kalangan remaja Tanjung Pinang saat ini makin meningkat. Tidak tanggung-tanggung remaja menggunakan tempat-tempat umum sebagai tempat berpacaran seperti di pusatpusat belanja, bioskop, kafe-kafe, tempat nongkrong remaja.

\section{Upaya Mengatasi Penyimpangan Perilaku Remaja}

1. Keharmonisan lingkungan keluarga harus tetap terjaga dengan baik, sehingga tercipta kenyamanan serta hubungan yang komunikatif antar individu yang ada di dalamnya.

2. Kontrol dan arahan orang tua terhadap teman sepermainan harus tetap dilakukan, di samping remaja itu sendiri cerdas dalam bergaul. Remaja membentuk ketahanan diri sehingga tidak gampang terpengaruh apabila kenyataannya teman sepergaulan atau komunitas yang ada tidak sesuai dengan perilaku yang diharapkan.

3. Kontrol tegas dari masyarakat atau pihak yang berwenang dalam menerapkan sanksi terhadap subkebudayaan masyarakat yang menyimpang untuk menimbulkan efek jera.

4. Selektif dalam mengakses informasi di media massa untuk menghindarkan diri dari pengaruh negatif.

5. Remaja diharapkan dapat menemukan figure yang mampu memberikan teladan atau orang-orang dewasa dengan prilaku baik dan mampu melewati masa remaja dengan baik dan mereka yang dapat memperbaiki diri setelah mengalami kegagalan pada tahap pencarian jati diri kepemudaannya.

6. Cemoohan atau ejekan dari masyarakat terhadap perilaku negatif remaja sehingga mereka malu untuk melakukan perbuatan yang melanggar norma.

\section{SIMPULAN}

Mengacu pada pembahasan di atas, dapat ditarik beberapa kesimpulan. Masa remaja adalah masa yang penuh kegalauan (emosional yang masih labil). Apabila hal tersebut tidak mendapat pengawasan yang optimal dari berbagai pihak maka akan berdampak negatif baik terhadap diri remaja itu sendiri maupun lingkungan sekitarnya.

Terjadinya penyimpangan perilaku remaja di perkotaan disebabkan oleh faktor internal dan eksternal. Bentuk-bentuk penyimpangan perilaku remaja di perkotaanm mengarah kepada perilaku tindak kriminal yang melanggar hukum. Diperlukan penanganan secara terpadu/sinergis baik melalui peningkatan peran dan fungsi keluarga, sekolah, maupun masyarakat. Dengan demikian, remaja sebagai generasi penerus benar-benar menjadi tumpuan harapan keluarga, masyarakat, dan bangsa. Remaja hendaknya memiliki kesadaran dan pengendalian diri yang kuat agar terhindar dari berbagai bentuk perilaku negatif, karena hal tersebut dapat merugikan masa depan remaja itu sendiri dan juga masa depan bangsa.

\section{DAFTAR PUSTAKA}

Adang, Y. A. (2013). Kriminologi. PT Refika Aditama.

Fikriyah, S., \& Febrijanto, Y. (2012). Faktorfaktor yang Mempengaruhi Perilaku Merokok pada Mahasiswa Laki-laki di Asrama Putra. Jurnal STIKES, 5(1), 100109.

Moleong, Lexy, J. (2010). Metodelogi penelitian Kualitatif. Remaja Rosda Karya Offset.

Narwoko, J. D. dan B. S. (2013). Sosiologi Teks Pengantar dan terapan. Kencana.

Pelly, U., \& Menanti, A. (1994). Teori-Teori Sosial Budaya. Dirjen Dikti Depdikbud.

Rahayuningsih, F. (2015). Hubungan antara Persepsi Perilaku Merokok dengan Perilaku Merokok Siswa SMK X di Kota semarang. Jurnal Kesehatan Masyarakat, 3(2), 220-229.

Rori, P. L. P. (2015). Pengaruh Pengguna Minuman Keras pada Kehidupan Remaja di Desa Kali Kecamatan Penelang Kabupaten Minahasa. Jurnal Holistik, VII(16).

Simangunsong, J. (2015). Penyalahgunaan Narkoba di Kalangan Remaja.

Siswendi, A. (2014). Perilaku Minumminuman Keras diKalangan Remaja di Kelurahan Sungai Salak Kecamatan 
Kampuling Kabupaten Indragiri Hilir. JOM FISIP, 1(2), 1-12.

Soekanto, S. (2012). Sosiologi: Suatu Pengantar. PT Raja Grafindo Persada.

Soelaeman, M. M. (2009). Ilmu Sosial Dasar:

Teori dan Konsep Ilmu Sosial (Edisi Revi). Refika Aditama.

Suriasumantri, Y. S. (2002). Filsafat Ilmu
Sebuah Pengantar Populer. Pustaka Sinar Harapan.

Umani, I., \& Panuju. (1999). Psikologi Remaja. Tiara Wacana.

Usman, S. (1998). Pembangunan dan Pemberdayaan Masyarakat. Pustaka Pelajar. 